\title{
Applying Canine Detection in Support of Collaborative Archaeology
}

\author{
John Grebenkemper $\odot$, Adela Morris, Brian F. Byrd, and Laurel Engbring
}

\section{ABSTRACT}

This article explores the use of specially trained canines to detect the location of human burials in nonmodern archaeological contexts. It discusses the history of the discipline, training and field methods, the importance of developing a working relationship with descendant communities, project examples, an assessment of canine detection effectiveness, and ways to select a canine detection team. The article highlights how the application of canine detection training and protocols to the archaeological record makes it possible to locate potential precontact Native American burial areas without ground disturbance. In some cases, probable burial areas located by canines can be confidentially mapped to ensure avoidance during upcoming construction projects. For a variety of reasons, many Native American communities have been wary of embracing this new method to locate ancestral burials. Today, however, canine detection is widely accepted by many tribal groups in California to locate ancestral burials that might be impacted by construction. Although additional controlled studies and rigorous field laboratory experiments are needed to understand the range of variation in efficacy fully, available results in both North America and Europe demonstrate that specially trained canines can often accurately locate human burials that are more than a thousand years old to within a few meters.

Keywords: canine detection of burials, collaborative archaeology, Indigenous burials, Native American, remote sensing

Este artículo explora el uso de caninos especialmente entrenados para detectar la ubicación de entierros humanos en contextos arqueológicos no modernos. Se discute la historia de la disciplina, la capacitación y los métodos de campo, la importancia de desarrollar de una relación de trabajo con las comunidades descendientes, ejemplos de proyectos, una evaluación de la efectividad de la detección canina y cómo seleccionar un equipo de detección canina. El documento distingue cómo la aplicación del entrenamiento y los protocolos de detección canina al registro arqueológico hace posible ubicar áreas potenciales de enterramiento de nativos americanos sin la perturbación de la tierra. En algunos casos, las áreas de enterramiento probables que son ubicadas por caninos pueden mapearse de manera confidencial para garantizar que se evite cualquier perturbación durante los próximos proyectos de construcción. Por diversas razones, muchas comunidades nativas americanas han sido cautelosas a la hora de adoptar este nuevo método para localizar entierros ancestrales. Hoy, sin embargo, la detección canina es ampliamente aceptada y promovida por muchos grupos nativo-americanos en California para localizar entierros ancestrales que podrían verse afectados por la construcción. Aun se necesitan estudios controlados adicionales y experimentos de laboratorio de campo rigurosos para comprender completamente el rango de variación en la eficacia, los resultados disponibles tanto en Norteamérica como en Europa demuestran que los caninos especialmente entrenados pueden frecuentemente localizar con precisión entierros humanos de más de mil años de antigüedad dentro de unos pocos metros.

Palabras clave: detección canina de entierros, arqueología colaborativa, entierros indígenas, Nativo americano, sensores remotos

Canines have been used to detect deceased human remains for more than two centuries, and the discipline has evolved immensely in that time. This article examines the application of specially trained canines to detect inhumed and cremated human burials recovered from nonmodern archaeological contexts.

Although the use of canines to identify the presence of human remains in varied archaeological contexts is still being refined, canine detection represents a powerful noninvasive remote sensing technique that can be employed as a complement to existing geophysical remote sensing methods. As such, it has broad application, and its demonstrable efficacy may appeal to
Indigenous communities, archaeological researchers, and land managers, providing an opportunity to unite these sometimes disparate groups under the common goal of protecting burial grounds and mortuary integrity.

This article specifically focuses on the application of the technique in precontact Native American archaeological sites, with key examples primarily drawn from California. For a variety of reasons, many Native American communities have been wary of embracing this new method to locate ancestral burials. Today, however, the use of canine detection to locate potential ancestral burials

Advances in Archaeological Practice 9(3), 2021, pp. 226-237

Copyright ( ) The Author(s), 2021. Published by Cambridge University Press on behalf of Society for American Archaeology. This is an Open Access article, distributed under the terms of the Creative Commons Attribution licence (http://creativecommons.org/licenses/by/4.0/), which permits unrestricted re-use, distribution, and reproduction in any medium, provided the original work is properly cited. 
without ground disturbance is widely accepted and promoted by many California tribal communities because it represents one of the most effective ways to identify, protect, and avoid archaeological or construction-related ground disturbance to mortuary areas. Although additional controlled studies and rigorous field laboratory experiments are needed to understand the range of variation in efficacy fully, available results in both North America and Europe demonstrate that specially trained canines can often accurately locate human burials that are more than a thousand years old to within a few meters.

Discussion commences with an overview of the history of this noninvasive technique, proceeds to detail training and field methods used, and then promotes the importance of developing a working relationship between canine handlers and Indigenous descendant communities. Select Native American project examples and results are provided, followed by an assessment of canine detection effectiveness and current limitations, considerations in selecting a canine detection team for a project, and a conclusion.

\section{HISTORY OF CANINE DETECTION OF BURIALS}

Human Remains Detection (HRD) dogs, commonly called cadaver dogs, have been trained to find recently deceased humans since the early 1970s. The first recorded use of a dog to find historic human remains was in 1987 when a New York sheriff deputy's cadaver-trained Labrador, Candy, located burials from the War of 1812 at Fort Erie, Ontario, Canada (Warren 2013).

The Institute for Canine Forensics (ICF), with which two of the authors are associated, was founded in 1998 specifically to train dogs to find ancient human burials. ICF refers to dogs trained to find old human burials as Historic Human Remains Detection (HHRD) dogs. Their specialized training distinguishes them from the HRD dogs who are trained to find the recently deceased. Since 1998, ICF has conducted numerous projects with a series of HHRD-trained dogs, notably in California, detecting historic burials and precontact Native American burials of varied antiquity, including some that are more than 9,000 years old (e.g., Engbring et al. 2019; Gallegos et al. 1989; Skowronek 2006). ICF primarily works through cultural resource management (CRM) firms, but in a few cases, it has been directly hired by the Indigenous community. Projects are primarily done before construction begins to determine areas that contain human remains.

HHRD dog work in Europe has similarly identified ancient human remains. Eva Cecil and her Border collie Ness worked on several archaeological sites in the Czech Republic. At a Neolithic site at Liboc, the dog alerted to numerous exposed graves in the archaeological excavation dated approximately 7,000 years ago (Bureš 2005; Eva Cecil, personal communication 2020). At Zličín, near Prague, Ness alerted to a previously unidentified grave that was revealed to be the intact tomb of a 12-year-old dated to 1,500 years ago by grave goods, including a glass vase in a niche above the burial (Figure 1; Eva Cecil, personal communication 2020; Velinský 2008). Similarly, a canine team in Croatia identified 19 areas of scent at Drvišica; five of them have since been excavated, with the oldest burial radiocarbon dated to $2740 \mathrm{cal}$ BP (790 BC; Glavaš and Pintar 2018).

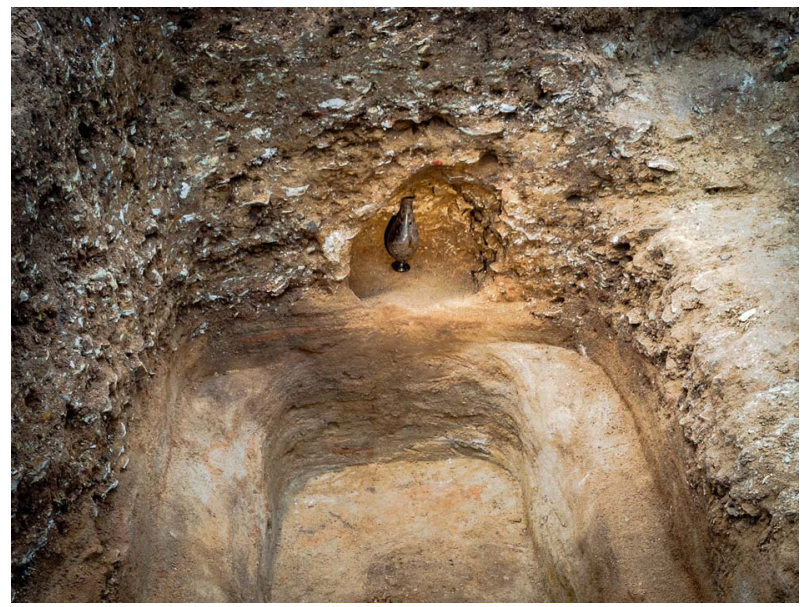

FIGURE 1. In 2007, Eva Cecil and canine Ness discovered an unknown burial tomb in Zličín, Czech Republic. Burial 1557/ 144 was of a 12-year-old child, and it contained an unbroken glass vase. This tomb, dated at AD 450, would likely have gone undiscovered without the canine search given that it was not in a known burial area at the archaeology site (photo (c) foto mARTin Frouz).

\section{TRAINING AND SEARCHING FOR SCENT FROM HUMAN BURIALS}

When a person dies, the decomposition process begins immediately and generates hundreds of different volatile compounds (Vass et al. 2008). When buried, these compounds are carried by water from the body into the bones and surrounding sediment, saturating both with the molecules that create the scent of human decomposition (Alexander et al. 2015). Some studies have shown that there is a large overlap in the decomposition of volatile compounds for humans and animals (Cablk et al. 2012), whereas some authors suggest that there could be a set of unique compounds for human decomposition that dogs are able to detect (Rosier et al. 2015). At this point, however, no one has identified a specific combination of decomposition compounds that allows dogs to identify the scent of an ancient human burial.

Although we may not have a complete scientific understanding of the chemical compounds involved, the canine nose is incredibly sensitive, capable of detecting some scents at levels of parts per trillion. Dogs have demonstrated that they can differentiate between decomposed human remains and other decomposing animals. HHRD dogs are therefore trained to locate the scent of human decomposition and ignore every other scent in a search area so as to avoid any possibility of misinterpreting the dogs' behavior when they detect other scents. Dogs best suited for this work are from a working or herding heritage, with emphasis on temperament and compatibility with humans. Training a dog to detect historic human remains is a process that takes several years to reach peak efficacy. Multiple exposures to burials of different ages and background scents are required for a dog to develop a scent profile of a deceased human.

Once dogs pass the initial ICF certification test, they are still required to participate in weekly training sessions and blind 
efficacy tests to locate hidden human bones throughout their working life. Some of these blind tests use human bones more than a thousand years old that are obtained from archaeological contexts in Europe. This helps them maintain a proven peak efficacy for when they participate in searches for historic and precontact burials. Most HRD scent training is focused on locating the desired scent targets. HHRD training must also include significant time in blind searches with no scent targets in the search area. Projects often include areas that contain no burials, and the dogs must be able to search such an area for several days with no alerts.

The dogs are required to train regularly at historic cemeteries, which provide a scent profile similar to ancient burials. Some of these cemeteries have burial headstones, whereas others show only a slight slump in the soil where the coffin has collapsed. The latter provide an excellent test of a dog's ability to detect old burials without any surface markers to provide a cue that a burial might be at this location.

In the field, HHRD dogs work slowly with their nose close to ground to detect the faint scent of old human decomposition. HHRD dogs are trained to alert only to a positive unambiguous scent, usually indicating through sitting or lying down that they have detected the desired scent at its point of maximum intensity. When the dog alerts, its nose will be close to the point of maximum scent intensity. The dog's handler can often observe when the dog has located scent, but only clear positive alerts are recorded. Areas of scent interest may be revisited later to see if the scent has increased enough for the dog to alert, based on changes in wind, temperature, and moisture levels.

A dog is a biological detector, and the environment will influence its ability to detect scent. High temperature, humidity, and wind will reduce the probability of detecting a burial. Heavy rain can keep scent from reaching the surface and evaporating into the air column. Thick grasses will trap the scent, and heavy vegetation will impede access to parts of the search area. All of these negative factors increase the likelihood that some burials will be missed.

For a dog to detect decomposition, the scent needs to reach the surface, where it can enter the air column and the dog's nostrils. There are multiple mechanisms that can transport scent from source to the surface. Given that a dog detects scent when it reaches the surface and passes into the air column, a trained dog's alert at the strongest location of the target scent may not always be directly above the burial. Diffusion through the ground is complex, with rodent, insect, and root activity providing excellent conduits for scent to pass upward and outward from a burial area. Water flowing through the ground can also carry scent away from the burial before it reaches the surface (Aitkenhead-Peterson et al. 2012).

An HHRD-trained dog can scent human decomposition even if the human remains are no longer present. For example, Chinese American immigrants customarily returned the bones of the deceased to their native villages in China. There were large shipments of bones known as jianyun ("bringing prosperity to descendants") returned to China during the nineteenth century (Chang 2019). Historic Chinese cemeteries in the western United States often retain excavation pits where the deceased were buried for a time before they were exhumed and returned home.
HHRD dogs have alerted at these pits because the associated sediment still retains the decomposition scent. HHRD dogs have also alerted in contexts where remains have been heavily affected by fire, successfully identifying cremated human remains in several North American settings including both precontact (e.g., Gamble 2017) and modern contexts (Cuthbert 2018).

When a deceased person is not buried, the same biochemical breakdown happens, but animal and insect activity may disperse the remains over a considerable area. The rate of decomposition varies depending on the local microenvironment, and ultimately, the remains decompose into the ground while the bones disintegrate on the surface. Such locations are detectable by HHRD dogs, and during a search for a probable location of old, unburied human remains, a wide area of interest and alerts are expected. For example, several locations of Donner Party deaths in the winter of AD 1846-1847 were detected by assessing the patterning of scattered alerts (Grebenkemper 2018; Grebenkemper and Johnson 2015).

\section{WORKING WITH INDIGENOUS DESCENT COMMUNITIES}

Archaeologists have viewed ICF's HHRD-trained dogs as a potentially noninvasive method for detecting human remains at historic and precontact archaeological sites. Canine detection has been combined with other techniques-such as oral history, past site surveys, historic documents, and maps, as well as remote sensing techniques such ground penetrating radar (GPR) and lidar - to provide more comprehensive insight into burial locations. Since the initial application of this technique to Indigenous archaeological sites, it has been a priority for ICF to build working relationships with Native American tribes, and in doing so, gain a better appreciation of their concerns and goals, particularly with respect to their perspectives on how best to protect the sacred burials of their ancestors.

It is important to acknowledge that using dogs to locate ancestral remains is not compatible with some Indigenous cultural beliefs, and doing so would rupture cultural taboos. Canine detection of human remains is not accepted by all Native American tribes or Indigenous scholars. We also appreciate that, for a variety of reasons (including historical trauma, the use of dogs in law enforcement, and the politics of oppression), Indigenous communities may feel that canine detection of buried human remains is invasive, insensitive, and disrespectful; that it shows a lack of understanding of traditional cultural beliefs; or that it could be considered an extension of colonial oppression. Therefore, it is important that the decision to use this approach rest solely with each Native American descendant community.

Consequently, we are not recommending that this detection method be applied in every context in which human remains may be present. Instead, we present examples of studies where canine detection was permitted and accepted by a tribe, as well as the results of such studies. It is not our intent to convince Indigenous communities to change their cultural taboos or worldviews. Our objective is to provide examples of how canine detection can be a useful and complementary method to geophysical remote sensing techniques that also do not involve ground disturbance if a 
descendant community supports and approves of the use of this technique.

ICF never searches for Indigenous burials without permission from the local Indigenous community leaders. A multifaceted plan was devised to begin this process in California. This consisted of

- Presenting at the California Tribal Historic Preservation Officers / State Historic Preservation (THPO/SHPO) summit, which allowed us to represent our capabilities, exchange ideas, and answer questions about the use of trained dogs

- Attending archaeology conferences, presenting papers, and participating in panel discussions on how to protect and avoid Native American burials

- Attending events such as the California Indian Conference, which allowed us to get an in-depth look at tribal concerns

- Attending and presenting at tribal council meetings, which also gave tribal members the opportunity to speak about their concerns regarding specially trained dogs

- Inviting local tribal members to observe the work we do with our dogs, listening to their concerns, and answering questions

Through this process, we gained a greater appreciation of the history of Native American experiences, the uniqueness of each tribe's cultural beliefs with respect to death, the importance of their ancestral burials, and their efforts to protect them. The priority is always not to disturb burials, and to avoid them in the context of construction projects. When that is not possible, the preference is to move and reinter them respectfully in an area nearby that will not be impacted by future construction.

Gaining the trust and support of Indigenous descendant communities has taken many years, and ICF greatly values these relationships. It is hoped that this approach and these experiences can be of use in Indigenous contexts elsewhere in North America. On many occasions, ICF canine teams have been honored to participate in traditional prayers or cleansing ceremonies when burials are present. We are very grateful and appreciative of the trust that has been placed with us, and we have included two examples of these experiences from the perspective of Native Californians.

The first statement represents one of the earlier experiences we had with the Kwaaymii Laguna Band of Indians from San Diego in Southern California. In this example, respected elder Carmen Lucas talks about her first experience working with ICF in 2007:

As a Native American who works as a Native Monitor, I have asked a million times, what makes it alright to dig up our ancestors' remains. My personal answer is "it is never okay." I consider disturbing our ancestors' remains a spiritual violation of the highest degree. I always have. And I always will. Avoidance of Human Remains, in any state or condition, is the first priority.

I learned about the Institute for Canine Forensics at a Society for California Archaeology Conference in 2006. Their dogs were trained to locate ancestral remains using non-destructive, non-invasive methods. While working on a highly sensitive archaeological project in 2007, I asked J. R. Cook, the owner of a CRM company at that time, to employ the ICF canine teams. Mr. Cook reluctantly agreed.

While I needed to know the accuracy of the canine teams, I was unwilling to excavate where they had alerted. I advised the ICF handlers that I needed to "test" their dogs and asked them if they would stay an extra day and survey my land. I know the location of some of the burials on my land and also suspected there were more. Each of the teams worked "blind" from the other teams, not knowing whether the other dogs had, or had not, alerted. Each of the teams alerted on the known burials, and at other burials I was unfamiliar with. All alerts were recorded utilizing GPS and documented on a map.

Six months later another opportunity to employ the ICF teams presented itself. A few handlers, including teams that had not previously worked the sensitive pre-contact site, surveyed the same area, again working independently of each other. All alerted where the previous teams had indicated the presence of pre-contact human remains. They also alerted on historic burials in the same location. Two individual maps were created by ICF, and the CRM company and each map indicated near identical accuracy.

During the 2007 project, on two different occasions, two ICF canines alerted, independently of each other, at approximately the same location. During construction in 2012, the impact of ground disturbance revealed an inhumation of some antiquity, approximately 9,600 \pm years of age.

Since the initial projects, the ICF canine teams have been employed on a number of other projects that I have been involved with. My experience is that the canine alerts have been $100 \%$ in locating areas where ancestral remains have been present.

Carmen Lucas

Kwaaymii Laguna Band of Indians

Ah Ha Mut Ta Tié, California [personal communication 2020]

The second statement, from working with Muwekma Ohlone of the San Francisco Bay area (Central California) in 2017, is a much more recent example. Here, tribal leaders Monica V. Arellano and Charlene Nijmeh, along with tribal archaeologist Alan Leventhal, discuss the employment of canines as part of the field methods during archaeological data recovery work.

Sii Túupentak (Place of the Water Round House) is a major Muwekma Ohlone ancestral heritage mortuary and village site located within our ethnohistoric territory of the intermarried Causen, Pelnen, Seunan, Tuibun, Jalquin, [and] Yrgin Chochenyo Ohlone-speaking tribal groups of the southeastern San Francisco Bay region, from who the majority of the lineages enrolled in our Tribe are directly descended from. When the San Francisco Public Utilities Commission (SFPUC) contacted our Tribal leadership about a proposed project to construct a major educational facility (called the Alameda Creek Watershed Center) adjacent to the historic Sunol Water Temple, we were alerted to the fact that an ancestral heritage resource was documented at this location. Although little was ascertained from a limited testing program, we were informed that fragments of human remains were recovered from this site.

After further discussions with our Tribal leadership and archaeologist/ethnohistorian, we agreed to enter into a partnership with the SFPUC and permit an archaeological data and burial recovery program (if encountered) to ensue with the provision that our leadership could select the archaeological/cultural resource management firm based 
on the following conditions: (1) a firm that our Tribe can trust to work with our leadership and be respectful in a meaningful way; (2) willing to work side-by-side with Tribal members as monitors and excavators during all phases of field work; (3) allowing our Tribal leadership and language committee to formally name this site in our Chochenyo language in both recognition and as part of our reclamation of our Tribe's ancestral heritage; (4) allowing our Tribal leadership to write a major ethnohistory of our historic ties to this locality and region; (5) allowing our Tribal leadership to have full input on the educational displays and programs planned for the Alameda Creek Watershed Center educational facility; (6) to have final input on the reburial of any of our ancestral remains and possible curation of non-burial related cultural and ecological materials; (7) recognizing the intellectual property belonging to our Tribe. As a result, our leadership requested entering in a partnership with Far Western Anthropological Research Group, Inc.

As with the careful exposure and documentation of any ancestral heritage site, and given the many unknown variables, especially when making extremely sensitive decisions on trying to avoid any adverse impacts to ancestral remains, a decision was made as part of the field methodology, by the former Muwekma Ohlone Tribal Chairwoman, Rosemary Cambra, to invite three canines from the Institute for Canine Forensics to be allowed on site in order for them to employ their sensitive olfactories to try to sniff out the potential locations of ancestral remains, located in areas of potential impact. To this non-invasive field method, our Tribal leadership was extremely interested in, especially since our long history of interdependence with dogs in Native California. We were quite pleased and surprised with the results of these canines to be able to recognize the presence of ancestral remains within the area designated for this independent test.

Thus began a collaborative relationship with the SFPUC, Far Western, [and] Institute for Canine Forensics, as well as the contributing scholars from various institutions of higher learning, and our Muwekma Ohlone Tribe at Síi Túupentak.

Monica V. Arellano, Muwekma Vice Chairwoman and MLD

Charlene Nijmeh, Muwekma Chairwoman

Alan Leventhal, Department of Anthropology, San Jose State University; Muwekma Tribal Archaeologist [personal communication 2020]

\section{NATIVE AMERICAN GRAVE DETECTION PROJECTS}

Information regarding the locations of graves is among the most sensitive topics for Native American tribal communities. This is not surprising given the historical trauma associated with the colonization of the Americas, which included grave looting and widespread site destruction. Earlier generations of archaeologists excavated Native American burials and associated mortuary remains with impunity, studied them, and then either displayed or housed them in museums without consultation of or permission from descendant communities. Out of respect for previous wrongs and to prevent future transgressions, grave location information needs to be protected and kept confidential, and the results of most ICF projects cannot be shared without permission of the descendant community.

In recent years, about $70 \%$ of ICF projects have been searching for Native American burials. Virtually all precontact projects had multiple Native American monitors observing these canine teams. We briefly highlight three examples from California where descendant community permission has been granted for publication.

\section{Síi Túupentak}

The protohistoric Ohlone ancestral settlement and mortuary site of Síi Túupentak is situated in the San Francisco Bay area (Central California) and was occupied primarily from 600 to 145 years ago (Byrd et al. 2020). The Muwekma Ohlone descendant community requested that a small portion of the site use remote sensing techniques, including HHRD canines, to locate ancestral burials prior to construction.

Three canine teams from ICF searched a $21 \times 14 \mathrm{~m}$ area and identified seven locations, with a total of 12 alerts (Figures 2 and 3). After complete archaeological excavation of this area, eight burials were identified along with three burials immediately adjacent to the search area (Engbring et al. 2019). The burials were directly dated from 525 to 382 cal BP (AD 1425-1568), with depths ranging from 10 to $100 \mathrm{~cm}$ below the surface.

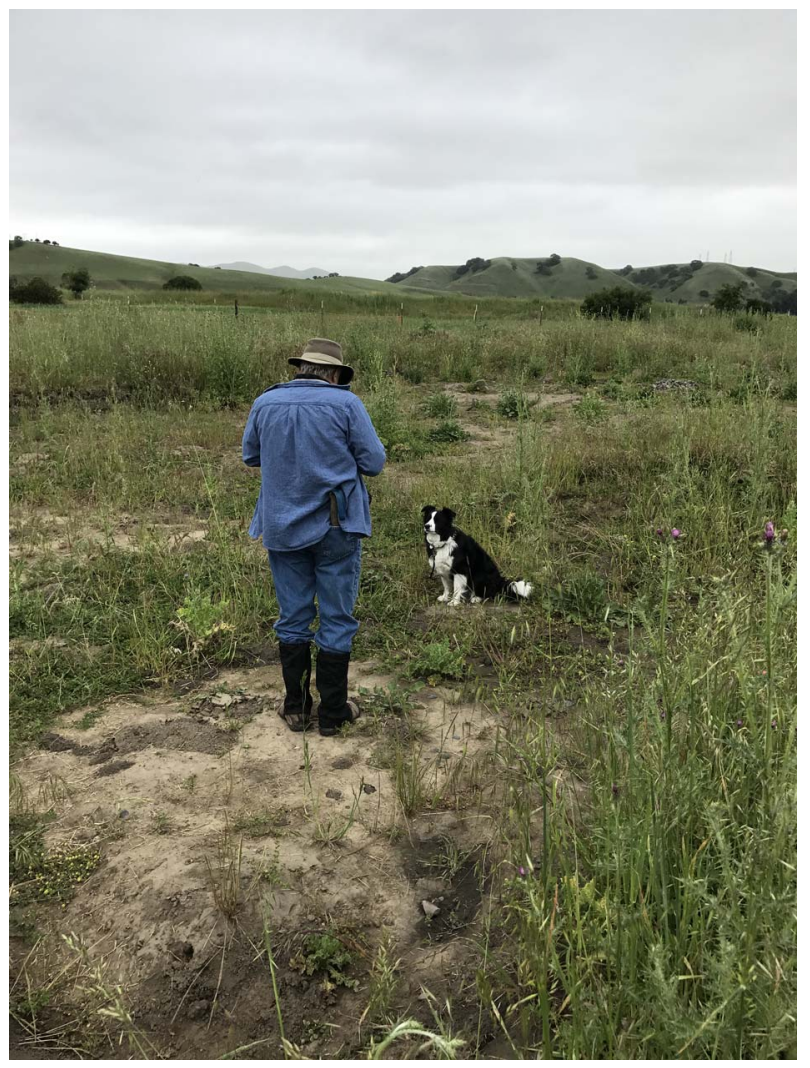

FIGURE 2. HHRD canine Kayle alerting at Síi Túupentak to a Native American burial. Burials at this site were removed before construction of a new building (photo by Shannon DeArmond, Far Western). 


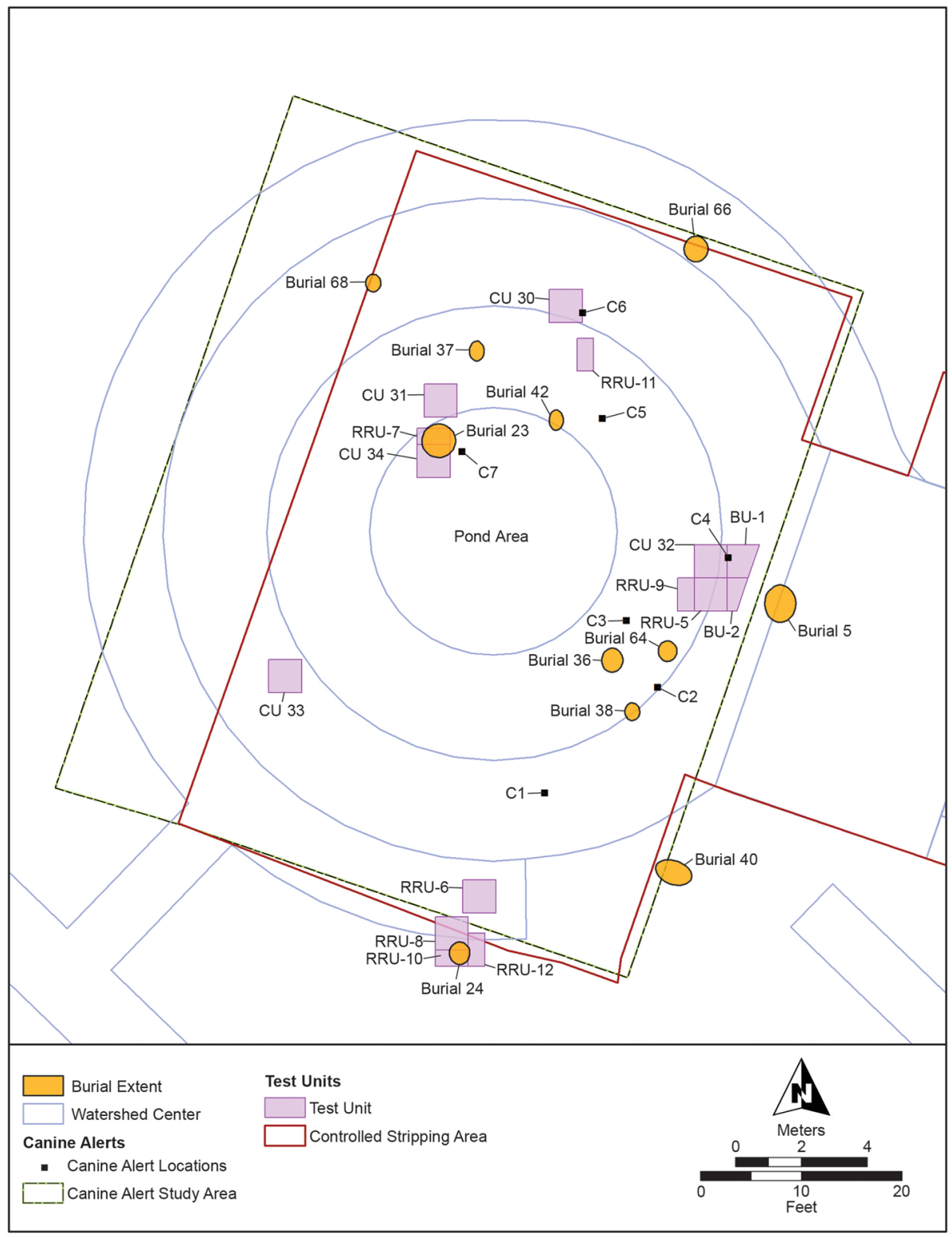

FIGURE 3. Alert Map of the Siii Túupentak site.

Also recovered were 165 isolated/disarticulated human remains, a site condition that made the canine search more challenging.

Although it cannot always be determined exactly to which burial a dog was alerting, the horizontal distance to the nearest burial ranged from 0.3 to $3.4 \mathrm{~m}$, with a mean distance of $1.6 \mathrm{~m}$. The deeper, typically older burials were consistently farther from the nearest alert than the more recent, shallower burials. Burial 37, the one cremation within the search area, was $3.1 \mathrm{~m}$ from the nearest alert. Burial $68(5.5 \mathrm{~m})$ and Burial 24 (5.2 $\mathrm{m}$, and outside the search area with observers standing on top of it) were the farthest from an alert, and it is possible that they were not detected. Burial 68 however, was also the youngest individual (less than six months old) and had the poorest macroscopic completeness, with less than $10 \%$ of elements recovered. Overall, due to the extensive excavation of the searched area, this project provided a rare opportunity to assess alert success and accuracy, false positives, and false negatives.

\section{Dripping Springs Site}

Dripping Springs is a late period (i.e., post 1,000-year-old) village site in Cuyamaca Rancho State Park in the mountains east of San Diego, where True (1970) excavated a cremation burial area. In 2008, renewed field school work by Gamble (2017) had ICF assess if HHRD dogs could confirm the cremation burial area location and determine if burials might be present elsewhere within the site.

The canine search was done blind, and each dog searching the area had no knowledge of the cremation burial area. Thirty-two 


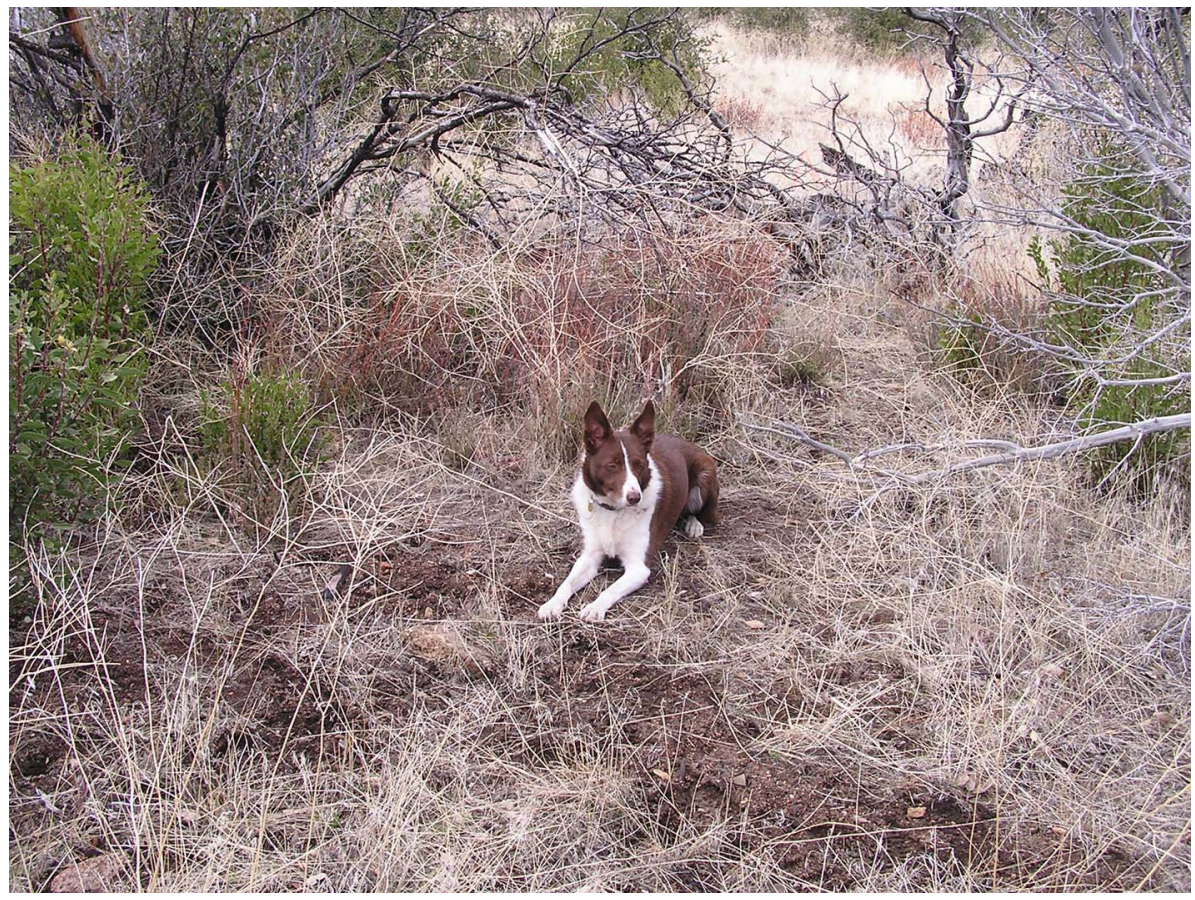

FIGURE 4. HHRD canine Rhea alerting at a cremation burial at Dripping Springs. The dog positions the alert so that her nose is near the location of strongest scent (photo by Adela Morris).

alerts were within or adjacent to the cremation burial area confirmed by Gamble (2017:82) using True's archival map of the burial ground. Several of these locations had alerts by multiple dogs. Another four alerts were $60-80 \mathrm{~m}$ away from the identified burial area. At the request of the Native American monitor, no students were allowed to do field studies within the burial grounds, and no verification via excavation was undertaken. Given that canine alerts were concentrated in the cremation burial area, the results strongly indicate that HHRD dogs can identify ancient cremations (Figure 4).

\section{Coastal Site in San Diego County}

The descendant community has requested that the site location not be directly disclosed when discussing this example from San Diego County in Southern California. In 2007 and 2011, six different ICF dogs searched part of this site for Native American graves before a construction project, identifying 14 potential burial areas with multiple alerts. During construction in 2012, one canine alert location was impacted by construction despite warnings by Native American monitors. A burial was indeed present and subsequently recovered at this location where five of the six dogs who had searched the site had alerted. The remains were not radiocarbon dated, but they are consistent with the remains of several individuals previously recovered nearby, all of which predate 9,000 years ago (Carmen Lucas, personal communication 2020).

Previously, burials have been recovered from multiple locations surrounding this 2012 exhumed burial (Bada et al. 1984; Gallegos et al. 1989; Kennedy et al. 1983). About 30 sets of human remains were recovered between 1929 and 1976 in multiple areas within this extensive site. Radiocarbon dating from the site has
Table 1. Radiocarbon Dating Results from Coastal Site in San Diego County.

\begin{tabular}{|c|c|c|c|c|}
\hline Sample & $\begin{array}{c}{ }^{14} \mathrm{C} \text { Age } \\
\text { BP }\end{array}$ & $\begin{array}{c}\text { Median cal } \\
\text { BP }^{\mathbf{a}}\end{array}$ & $\begin{array}{c}2 \sigma \text { cal BP } \\
\text { Range }^{\text {a }}\end{array}$ & Reference \\
\hline PTA-1809 & $8330 \pm 160$ & 9377 & 8994-9782 & $\begin{array}{l}\text { Gallegos et al. } \\
1989\end{array}$ \\
\hline PTA-1812 & $8350 \pm 90$ & 9431 & 9198-9552 & $\begin{array}{l}\text { Gallegos et al. } \\
1989\end{array}$ \\
\hline PTA-1725 & $8360 \pm 75$ & 9451 & $9255-9551$ & Kennedy 1983 \\
\hline OXA-0154 & $8470 \pm 140$ & 9453 & $9070-9774$ & $\begin{array}{c}\text { Bada et al. } \\
1984\end{array}$ \\
\hline
\end{tabular}

a Reimer et al. 2013

consistently demonstrated that the burials predate $9000 \mathrm{cal}$ BP (7050 BC; Table 1), representing some of the oldest dated burials in California.

\section{ASSESSING CANINE DETECTION EFFECTIVENESS AND LIMITATIONS}

A dog is a binary detector that indicates the presence or absence of human decomposition scent. An alert is a distinct action by the dog that indicates that it has detected scent. Lack of alert indicates that the scent is below the dog's threshold of detection. It does not, however, mean that an ancient burial is not presentonly that it cannot be detected. We can assess the efficacy and usefulness of HHRD dog alerts by several characteristics: 
probability of detection, detection precision, probability of false positives, and age range of burial detection. It is important to note that although canine detection is an evolving science that will improve with further research, the efficacy of this technique is comparable to that of other more widely utilized remote sensing techniques such as GPR and lidar. In all remote sensing techniques, the data is subject to interpretation, and there is a potential for false positives or negatives. As such, all remote sensing techniques require ground truthing and carrying out controlled studies that assess what variables effect efficacy. Unfortunately, published remote sensing controlled studies are rare at present, and much more work of this nature is needed.

\section{Probability of Detection}

The probability that a dog will detect a burial is dependent on many factors, including burial antiquity, sediment, disturbance or environmental conditions that might destroy scent, vegetation, animal hazards, and search-day weather conditions (air and ground temperature, humidity, wind, rain, soil moisture, cloud cover, and shade). Weather conditions may reduce scent or prevent detection entirely, given that ancient burial scent levels may be close to a dog's detection threshold.

Scent intensity can vary greatly. For example, during one ICF project, two dogs were able to detect numerous burials in their search area in the morning. Two different dogs working the same search area a few hours later under different conditions were unable to detect scent from many of the previous alerts.

Multiple dogs searching the same area invariably improves the probability of detection. In some cases, the scent is time variable, whereas in other cases, the dogs follow slightly different search paths through the search area. If the scent is near the threshold of detection, a dog may have to pass almost directly over the scent source to detect it. Critical or suspicious alerts by a single dog should always be confirmed by other dogs on the team.

To determine the probability of detection conclusively requires unambiguous field verification via stripping the entire search area to sterile sediment in order to find all burials and then compare the results with dog alerts. For ICF projects, only the work at Síi Túupentak meets that assessment threshold, but the modest $21 \times$ $14 \mathrm{~m}$ area is small for rigorous statistical analysis and complicated by the presence of considerable disarticulated human remains. The results, however, were very encouraging, with 12 alerts at seven locations, and the subsequent recovery of eight burials within the search area, four of which were less than a meter from the nearest alert (Engbring et al. 2019).

\section{Detection Precision}

Detection precision is the horizontal distance between canine alert of the scent and the actual subsurface human remains. As discussed previously, the scent propagation path from a burial often does not travel straight up to the surface. Instead, it takes the path of least resistance, which may be offset from the grave due to various factors. For example, ICF worked at a historic burial on a hillside, previously located by remote sensing. The two dogs on the search alerted $5 \mathrm{~m}$ downslope of the grave, likely due to water flow carrying the scent downhill.
When we measure detection precision, it is impossible to separate the scent propagation path to the surface and the error that the dog makes in alerting to the scent. It is only possible to measure detection precision when we have some means to measure the location of burials, either through remote sensing or excavation.

ICF generally estimates that dog alerts are within $4 \mathrm{~m}$ of the grave, based on observations of canine alerts in twentieth-century cemeteries. A $2 \mathrm{~m}$ deep burial in homogenous sediment will have an expected scent cone that extends several meters beyond the burial, and inhomogeneities can extend the scent cone even further. A $4 \mathrm{~m}$ radius estimate sometimes provides land managers with practical off-limits area for avoidance during development projects.

Three projects have measured detection precision of a canine search (Table 3). A confidential Midwest project used the dogs to determine the location of burials in several historic mid-nineteenthcentury cemeteries. Grave locations were determined by several remote sensing technologies. The Fort Gordon project was conducted on behalf of the Army Corps of Engineers to determine the effectiveness of dogs to locate cemeteries on military bases (Baxter and Hargrave 2015). Graves were located using GPR, and an extensive report was written on canine effectiveness. The Síi Túupentak project was the only Native American burial area to measure the detection precision of a canine search. Burials were, on average, $2.5 \mathrm{~m}$ from an alert, and only two burials were more than $4 \mathrm{~m}$ from the nearest alert (Engbring et al. 2019).

Different groups publish the precision using different terminology. The various maps of alerts and burials were converted to a common unit of circular error probable (CEP). This is the diameter of a circle around the burial that will contain $50 \%$ of the dog alerts. It works well for measuring any process that is attempting to locate a fixed position on earth. The higher CEP of the Fort Gordon site is likely due to deeper burials in the twentieth century than the hand-dug graves at the other two sites. The uncertainty of scent propagation to the surface is roughly proportional to the depth of the burial.

\section{Probability of a False Positive}

The only way to determine conclusively if an alert is a false positive is via excavation. Even then, the alert could be correct, but the human remains may be situated beyond the area excavated, or residue scent may remain in the sediment, such as in the example provided of historic Chinese burials. As a result, we currently do not have strong data to estimate the frequency of false positives.

In 2013, ICF was asked to search the archaeological collection at Mission San Antonio de Padua for scent from burials in a multidecade collection by Robert L. Hoover (2019) of material from Native American sites around the mission. The collection did not intentionally contain any human remains, but it was possible that small bone fragments may have inadvertently been curated. The collection was contained in 182 cardboard boxes placed outside in multiple lines with roughly a $1.5 \mathrm{~m}$ separation. Three ICF dogs were asked to check each box and indicate if it contained the scent of human remains (Figure 5).

In independent searches, the dogs had a total of 43 alerts on 22 boxes. Seven of the 182 boxes had alerts by all three dogs. Monte Carlo analysis shows that the probability of this occurring by random chance is 20 parts per billion, which implies that dog alerts 
Table 2. Age of Canine-Detected Ancient Burials.

\begin{tabular}{|c|c|c|c|c|}
\hline $\begin{array}{c}\text { Age } \\
(\text { cal BP) }\end{array}$ & Location & Dating Method & $\begin{array}{l}\text { Type of Canine } \\
\text { Search }\end{array}$ & Reference \\
\hline $382-525$ & $\begin{array}{l}\text { Síi Túupentak, Central } \\
\text { California }\end{array}$ & Direct ${ }^{14} \mathrm{C}$ dating & Blind & Engbring et al. 2019 \\
\hline $543-1297$ & $\begin{array}{l}\text { CA-ALA-343, Central } \\
\text { California }\end{array}$ & $\begin{array}{l}{ }^{14} \mathrm{C} \text { dating of burial-associated } \\
\text { shell beads }\end{array}$ & Known & Byrd et al. 2017; Hall 1985 \\
\hline 1500 & Zličín, Czech Republic & Time-sensitive grave artifacts & Blind & $\begin{array}{l}\text { Velinský 2008; Eva Cecil, personal } \\
\text { communication } 2020\end{array}$ \\
\hline 2740 & Drvišica Hillfort, Croatia & ${ }^{14} \mathrm{C}$ & Blind & Glavaš and Pintar 2018 \\
\hline$\sim 7000$ & Liboc, Czech Republic & Time sensitive Neolithic artifacts & Known & $\begin{array}{l}\text { Bureš 2005; Eva Cecil, personal } \\
\text { communication } 2020\end{array}$ \\
\hline 9377-9453 & $\begin{array}{l}\text { San Diego County, Southern } \\
\text { California }\end{array}$ & Direct ${ }^{14} \mathrm{C}$ dating of four burials & Blind & $\begin{array}{l}\text { Bada et al. 1984; Gallegos et al. 1989; } \\
\text { Kennedy } 1983\end{array}$ \\
\hline
\end{tabular}

${ }^{a}$ Reimer et al. 2013.

Table 3. Detection Precision of Dog Alerts.

\begin{tabular}{llccc}
\hline \multicolumn{1}{c}{ Location } & Site & $\begin{array}{c}\text { Published } \\
\text { Precision }\end{array}$ & $\begin{array}{c}\text { Circular Error } \\
\text { Probable }\end{array}$ & Reference \\
\hline U.S. Midwest & $\begin{array}{c}\text { Ninetenth-century historic } \\
\text { cemeteries }\end{array}$ & $\mathrm{n} / \mathrm{a}$ & $<1.1 \mathrm{~m}$ & Confidential \\
Ft. Gordon, Georgia & $\begin{array}{c}\text { Five early twentieth-century } \\
\text { cemeteries }\end{array}$ & $61 \%$ of alerts $<4 \mathrm{~m}$ & $<2.8 \mathrm{~m}$ & $\begin{array}{c}\text { Baxter and Hargrave } \\
2015\end{array}$ \\
$\begin{array}{l}\text { San Francisco Bay Area, } \\
\text { California }\end{array}$ & Síi Túupentak & Average $1.6 \mathrm{~m}$ & $<1.4 \mathrm{~m}$ & Engbring et al. 2019 \\
\hline
\end{tabular}

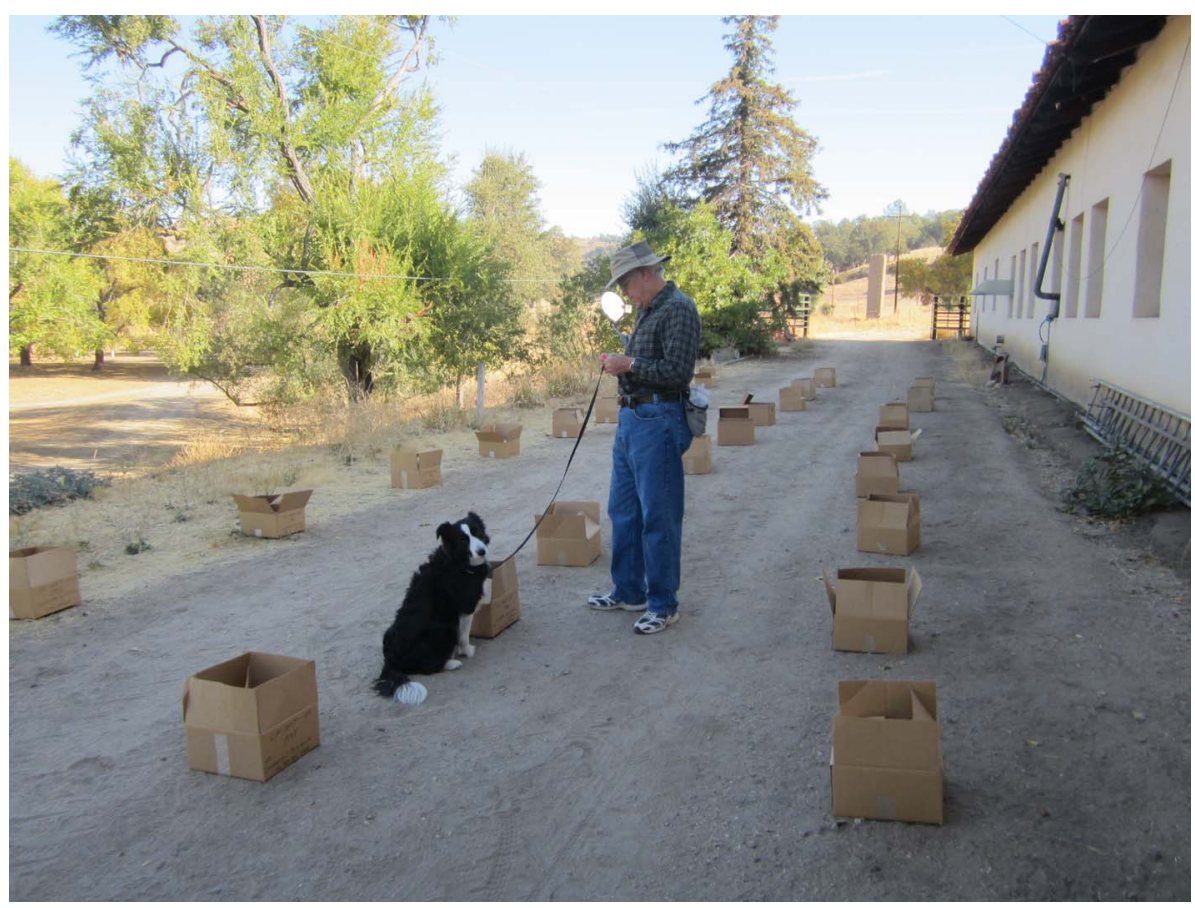

FIGURE 5. Kayle and the author John Grebenkemper searching boxes of the Mission San Antonio de Padua archaeology collection for evidence of human remains. Kayle is sitting next to a box, which indicates that it contains the scent of human remains (photo by Robert L. Hoover). 
were due to the scent of human remains. Eight boxes had alerts by a single dog. Most likely, the scent was weaker, and some dogs missed detecting it. If we assume, however, that all eight singledog alerts were incorrect, we calculate the upper limit for a single-dog false positive as $2.4 \%$ at a $95 \%$ confidence level using a binomial probability distribution. Assuming statistical independence, the probability that two dogs would have a false positive at the same box is less than $0.06 \%$.

Extending this to field searches, two dogs alerting in the same area implies a high degree of certainty that the area contains human decomposition scent. Overall, we suggest that most single dog alerts are correct because the dogs are regularly tested for false positives. Given that the amount of scent varies with environmental factors, scent could be present when one dog searches an area but not detectable when another dog searches the same area hours or days later.

\section{Age Range of Burial Detection}

Numerous dogs from different search groups have detected burials that vary in age from several hundred to several thousand years old in both North America and Europe. Native American burials are rarely excavated unless the remains need to be moved for a construction project. Even if remains are recovered, the tribes only infrequently allow them to be directly radiocarbon dated, and ages then must be estimated by indirect methods. Table 2 lists six sites with good temporal resolution of canine-detected ancient burials, revealing the potential for human burials over 9,000 years old to be detected by canine searches.

\section{SELECTING A HHRD SEARCH TEAM}

There is no national standard for certifying dogs to detect ancient burials. Anyone utilizing these services needs to verify carefully that the contractor is qualified to provide the service as advertised. Anyone can claim that they have a dog that detects ancient human burials. The following are some simple enquiries that should be made before contracting HHRD dog services:

- Request a list of clients and projects worked for those clients. Check references with clients regarding their satisfaction with the canine work. How many HHRD projects per year does the search team support?

- Request sample reports that document the canine search results. Many client reports are confidential and cannot be provided without the client's permission.

- How are the dogs certified to show they can detect HHRD burials? Request documentation of the skills required for handler and dog certification.

- Have the dogs been tested by an independent archaeologist to determine their effectiveness at detecting human burials? What were the results?

- How many handler/dog teams are available to work projects?

- What other scents are the dogs trained to detect?

- Request copies of papers that have been published on the dog team.

The answers will provide some guidance on which groups may have a better fit for the desired search. In particular, dogs trained on multiple scents may be less effective than dogs trained on a single scent. For example, if dogs are trained on both explosives and HHRD, how will they react if they encounter the scent of explosives from fertilizer in the search area while searching for ancient burials? The number of deployable teams may be an issue, especially on projects that need to cover a larger area or have temporal constraints. Single dog deployments should be avoided because they will have a lower probability of detection, and there is no way to cross-check suspicious alerts that might be a false positive.

\section{CONCLUSIONS}

In summary, canines have been used for more than a century to assist humans in the detection of various scents, including locating human residues and remains in contexts of varied nature and age. Over the last two decades, this expertise has been developed to detect human burials of varied antiquity within the United States and abroad. The application of this process to the archaeological record makes it possible to locate potential precontact Native American burial areas without ground disturbance. In some cases, probable burial areas located by canines can be confidently mapped to ensure avoidance during upcoming construction projects, limiting expensive and time-consuming mitigation processes.

Descendant communities highly value the protection of ancestral burials from disturbance and development. This is particularly true for Native Americans, who have experienced widespread loss of traditional lands and associated historical trauma. During much of the twentieth century, development and archaeological investigations occurred without consultation or consent of the local Indigenous peoples. Canines may also have negative connotations for Native American people, both within traditional religious contexts and due to modern policing methods, which inordinately impact minorities in North America. Given these circumstances, many Native American communities have been wary of embracing this new method to locate ancestral burials. It has consequently been a slow process for canine detection to be viewed as a way to limit disturbance of burials. Today, canine detection is widely accepted by many tribal groups in California as one of best ways to locate ancestral burials that might be impacted by construction plans. In some cases, tribes have requested the use of trained HHRD dogs over other remote sensing technologies, which have similar limitations.

Canines can be trained to find only the scent of human remains and ignore those of other species. Canine efficacy can be determined by four parameters: age of detected burials, distance between alert and grave, probability of false positive, and probability of detection. These parameters can be estimated through case studies where all burials are identified and removed from a search area during a construction project. In most projects where burials are left in situ, efficacy cannot be determined. Many more controlled studies and rigorous field laboratory experiments are needed to fully understand the range of variation in efficacy.

Much of the evidence presented in this article is based on observations by multiple individuals with multiple dogs working on historic and precontact burials over several decades. The need to keep burial locations confidential prevents the results of most canine searches at archaeological sites from being published, and there is consequently a paucity of data on the subject publicly 
available. A few tribes, however, have consented to publication of the results of canine searches in areas where burials were removed during development projects. Available results from academic research in both North America and Europe show that specially trained canines can, in at least many circumstances, accurately locate human burials more than a thousand years old to within a few meters, highlighting the utility of this technique in a wide range of contexts (Bureš 2005; Glavaš and Pintar 2018; Skowronek et al. 2006). This may benefit and find support among descendant communities, archaeological and historical researchers, preservationists, CRM professionals, land managers, and agency officials such as SHPOs. Additional studies utilizing this noninvasive remote sensing method will hopefully provide clarification on efficacy and limitations, further enhancing our understanding of the way in which human-canine partnerships can benefit society.

\section{Acknowledgments}

We thank Martha Longo-Diaz for providing the Spanish translation of the abstract. JG and AM thank Carmen Lucas of the Kwaaymii Laguna Band of Indians for her support of HHRD projects and review of the description of several searches. BB and LE thank the Muwekma Ohlone Tribe of the San Francisco Bay Area (particularly Vice Chair Monica Arellano, former Tribal Chair Rosemary Cambra, current Tribal Chair Charlene Nijmeh, and Tribal Ethnohistorian Alan Leventhal) for collaborating on the archaeological mitigation investigations at Sii Túupentak. We also thank the San Francisco Public Utilities Commission for its support of the Síi Túupentak project (particularly Kimberly Stern Liddell, Bryan Deassaure, Carla Schultheis, and Deborah Craven-Green).

\section{Data Availability Statement}

All data concerning Native American burials is confidential and was included with the consent of the descendant community.

\section{REFERENCES CITED}

Aitkenhead-Peterson, J. A., C. G. Owings, M. B. Alexander, N. Larison, and J. A. Bytheway

2012 Mapping the Lateral Extent of Human Cadaver Decomposition with Soil Chemistry. Forensic Science International 216:127-134.

Alexander, Michael B., Theresa K. Hodges, Joan Bytheway, and Jacqueline A. Aitkenhead-Peterson

2015 Application of Soil in Forensic Science: Residual Odor and HRD Dogs. Forensic Science International 249:304-313.

Bada, J. L., R. Gillespie, J. A. J. Gowlett, and R. E. M. Hedges

1984 Accelerator Mass Spectrometry Radiocarbon Ages of Amino Acid Extracts from Californian Palaeoindian Skeletons. Nature 312:442-444

Baxter, Carey L., and Michael L. Hargrave

2015 Guidance on the Use of Historic Human Remains Detection Dogs for Locating Unmarked Cemeteries. U.S. Army Corps of Engineers, Engineer Research and Development Center (ERDC/CERL TR-15-36), Champaign, Illinois.

Bureš, Michal

2005 Nová výstavba rezidenční čtvrtě Nová Liboc. Archaia praha výroční zpráva za rok 2004:21-22. (New Construction of the Nová Liboc Residential Area. Archaia Prague Annual Report 2004:21-22.)

Byrd, Brian F., Laurel Engbring, Michael Darcangelo, and Allika Ruby 2020 Protohistoric Village Organization and Territorial Maintenance: The Archaeology of Sii Túupentak (CA-ALA-565/H) in the San Francisco Bay Area. Center for Archaeological Research at Davis, Davis, California.
Byrd, Brian F., Adrian Whitaker, Patricia Mikkelsen, and Jeffrey Rosenthal 2017 San Francisco Bay-Delta Regional Context and Research Design for Native American Archaeological Resources, Caltrans District 4. Report submitted to Caltrans District 4, Oakland, California. Electronic document, https://dot.ca.gov/-/media/dot-media/programs/environmental-analysis/ documents/ser/sf-bay-delta-research-design-2017-a11y.pdf, accessed December 1, 2020.

Cablk, Mary E., Erin E. Szelagowski, and John C. Sagebiel

2012 Characterization of the Volatile Organic Compounds Present in the Headspace of Decomposing Animal Remains, and Compared with Human Remains. Forensic Science International 220:118-125.

Chang, Gordon H.

2019 Ghosts of Gold Mountain. Houghton Mifflin Harcourt, Boston.

Cuthbert, Lori

2018 How Sniffer Dogs Find Cremated Human Remains after Wildfires. National Geographic, 30 October. https://www.nationalgeographic.com/ animals/2018/10/sniffer-dogs-human-remains-california-wildfires-cremationnews/?, accessed September 1, 2020.

Engbring, Laurel, Brian F. Byrd, John Grebenkemper, Adela Morris, Monica V. Arellano, and Alan Leventhal

2019 Assessing Canine Forensic Results with Archaeological Excavations at Protohistoric Site Sii Túupentak (CA-ALA-565/H) in the San Francisco Bay Area. Proceedings of the Society for California Archaeology 33:239-245.

Gallegos, Dennis, Roxana Phillips, Andrew Pigniolo, Tom Demere, and Patricia M. Masters

1989 A Cultural and Paleontological Inventory Update for the University of California at San Diego and Scripps Institution of Oceanography. Manuscript SD-00827 on file, State of California South Coastal Information Center, San Diego State University, San Diego, California.

Gamble, Lynn H.

2017 Archaeology of the Kumeyaay: Contributions to the Prehistory of Cuyamaca Rancho State Park, San Diego County, California. Cultural Resources Division, Publications in Cultural Heritage No. 34, California Department of Parks and Recreation. Electronic document, https://www. parks.ca.gov/pages/22491/files/CA_State_Parks_Archaeological_Report_ Vol34_Cuyamaca\%20(reduced).pdf, accessed August 1, 2020.

Glavaš, Vedrana, and Andrea Pintar

2018 Human Remains Detection Dogs as a New Prospecting Method in Archaeology. Journal of Archaeological Method and Theory 26:1106-1124.

Grebenkemper, John

2018 Starved Camp of the Donner Party, Overland Journal 36:77-82.

Grebenkemper, John, and Kristin Johnson

2015 Forensic Canine Search for the Donner Family Winter Camps. Overland Journal 33:64-89.

Hall, Jeffery $T$.

1985 Results of an Archaeological Subsurface Testing Program at CA-ALA-343. Center for Anthropological Research, San Jose State University, San Jose, California. On file, Northwest Information Center, Sonoma State University, Rohnert Park, California.

Hoover, Robert L.

2019 RESURGAM Mission San Antonio de Padua, Journal of the California Missions Foundation 35:45-58.

Kennedy, G. E.

1983 An Unusual Burial Practice at an Early California Indian Site. Journal of New World Archaeology 3:4-6.

Reimer, Paula J., Edouard Bard, Alex Bayliss, J. Warren Beck, Paul G. Blackwell, Christopher Bronk Ramsey, Caitlin E. Buck, Hai Cheng, R. Lawrence Edwards, Michael Friedrich, Pieter M. Grootes, Thomas P. Guilderson, Haflidi Haflidason, Irka Hajdas, Christine Hatté, Timothy J. Heaton, Dirk L. Hoffmann, Alan G. Hogg, Konrad A. Hughen, K. Felix Kaiser, Bernd Kromer, Sturt W. Manning, Mu Niu, Ron W. Reimer, David A. Richards, E. Marian Scott, John R. Southon, Richard A. Staff, Christian S. M. Turney, and Johannes van der Plicht

2013 IntCal13 and Marine13 Radiocarbon Age Calibration Curves 0-50,000 Years Cal BP. Radiocarbon 55:1869-1887.

Rosier, E., S. Loix, W. Develter, W. Van de Voorde, J. Tytgat, and E. Cuypers 2015 The Search for a Volatile Human Specific Marker in the Decomposition Process. PLoS ONE 10(9):e0137341. DOI:10.1371/journal.pone.0137341, accessed March 26, 2021. 
Skowronek, Russell, Eva Cecil, Shirley Hammond, Warren Kirsch, Patricia Lamson, Adela Morris, Bev Peabody, and Lorna C. Pierce

2006 Going to the Dogs: Human Remains Detection Dogs in Archaeology. Indian Journal of Physical Anthropology and Human Genetics 25(2):151-166.

True, Delbert L.

1970 Investigation of a Late Prehistoric Complex in Cuyamaca Rancho State Park, San Diego County, California. Archaeological Survey Monograph. Department of Anthropology, University of California, Los Angeles.

Vass, Arpad A., Rob R. Smith, Cyril V. Thompson, Michael N. Burnett, Nishan Dulgerian, and Brian A. Eckenrode

2008 Odor Analysis of Decomposing Buried Human Remains. Journal of Forensic Science 53:384-391.

Velinský, Frederik

2008 Ojedinělý objev: Hroby z bouřlivých časů (A Unique Discovery: Graves from Stormy Times). 21 Stoleti 2008:111-113. Electronic document, https:// 21 stoleti.cz/2008/10/18/ojedinely-objev-hroby-z-bourlivych-casu/, accessed August 1, 2020.
Warren, Cat

2013 What the Dog Knows: Scent, Science, and the Amazing Ways Dogs Perceive the World. Simon and Schuster, New York.

\section{AUTHOR INFORMATION}

John Grebenkemper Institute for Canine Forensics, 19490 Miller Court, Saratoga, CA 95070, USA (johngicf@yahoo.com, corresponding author)

Adela Morris Institute for Canine Forensics, PO Box 620699, Woodside, CA 94062, USA (adela@prusik.com)

Brian F. Byrd and Laurel Engbring $\square$ Far Western Anthropological Research Group Inc., 2727 Del Rio Place, Davis, CA 95618, USA

(brian@farwestern.com) 